\title{
Effect of Cold Maceration and Thermovinification on Sensory Evaluation of Jamun (Syzigium cuminii L.) Wine
}

\author{
Hanamant R. Holegar ${ }^{1 *}$, G.J. Suresha ${ }^{2}$, S.L. Jagadeesh ${ }^{3}$ and A.K. Vandana ${ }^{1}$ \\ ${ }^{1}$ Department of Post-Harvest Technology, KRCCH, Arabhavi (UHS, Bagalkot), Karnataka, India \\ ${ }^{2}$ Department of Post-Harvest Technology, COH, Bengaluru (UHS, Bagalkot), Karnataka, India \\ ${ }^{3}$ Department of Post-Harvest Technology, COH, Bagalkot (UHS, Bagalkot), Karnataka, India \\ *Corresponding author
}

\section{A B S T R A C T}

The present investigation on cold and heat maceration was carried out to know the

Keywords

Jamun, Cold, Heat,

Maceration and

Sensory

evaluation.

Article Info

Accepted:

29 June 2017

Available Online:

10 July 2017 sensory quality of Jamun wine was evaluated. Jamun wine was prepared from three different must types viz., juice, pulp + skin and pulp + skin + seed were exposed to cold soaking and heat maceration of about $8^{\circ} \mathrm{C}$ for five days and $82^{\circ} \mathrm{C}$ for two minutes, respectively. The physicochemical and sensory quality of the wine was recorded in fresh, three and six months. Organoleptic evaluation for all the quality attributes like appearance, colour, aroma and bouquet, acidity, sweetness, body, flavour, astringency, overall quality and total score were showed significant differences. The wine produced from thermovinification and must of pulp and skin $\left(\mathrm{T}_{8}\right)$ secured the highest score and $\mathrm{T}_{1}$ (Juice) secured lowest score at six months of ageing. The quality of jamun wine can be improved by adopting novel maceration techniques and there is a great scope for utilization of jamun fruits for wine making to reduce the post-harvest loss.

\section{Introduction}

The jamun (Syzygium cumini L.) is an important unexploited indigenous fruit of the tropics, belonging to the family Myrtaceae. It has recently the major importance as an arid zone horticultural crop because of its hardy nature and high yielding potential. It is known by several names, such as black plum, black berry and java plum. It is also known in India by a number of local names, such as jamun, rajamun, jambhul, kalajam, phalani and phalinda (Singh et al., 1963). Jamun fruits possess good taste and pleasant flavour. The attractive colour of the pulp is due to the presence of anthocyanin pigment and is mostly used for dessert purpose. The fruits are also used for preparation of delicious beverages, jellies, jam, squash, wine, vinegar and pickles (Orchse et al., 1961). The ripe jamun fruits are used for making preserves, squashes and jellies. A good jelly and jam can be prepared from ripe jamun fruits (Anon., 1976).

Cold soaking/maceration is known to increase the prefermentation skin contact time. After crushing of the grapes the vacuoles of the skin cells are broken and the anthocyanins can seep out. The absence of alcohol at that time, 
allows the formation of higher molecular weight pigmented phenolic species which will enhance colour stability (McMahon et al., 1999). Thermovinification is a process where whole or crushed grapes are heated to a temperature between $60-80{ }^{\circ} \mathrm{C}$ for $20-30$ minutes to promote the diffusion of phenolic and colour compounds from the grape skins (Ribereau-Gayon et al., 2000). The heating damage the hypodermal cell membranes and the anthocyanins are released (Lowe et al., 1976; Sacchi et al., 2005).

\section{Materials and Methods}

The present investigation on was carried out in the laboratory of Department of PostHarvest Technology, Kittur Rani Channamma College of Horticulture, Arabhavi, during the period 2012 - 2014.Jamun fruits were brought from the orchard of Kaitanal village located near Gokak city to conduct the experiment. Ripe and healthy fruits with different size were used for the experiments. Fruits were processed together in order to maintain homogeneity of the experimental material. The selected fruits were squeezed to extract the pulp and separated the seeds with hands.

The three types of must viz., juice, pulp + skin and pulp + skin + seed were exposed to cold soaking of about $8^{\circ} \mathrm{C}$ for five days and after which the must was normalized for ambient temperature and the yeast culture was added to all the samples at the rate of $0.2 \%$ and kept for aerobic fermentation for 24 hours. For thermovinification, the three different musts were exposed to heat treatment at $82^{\circ} \mathrm{C}$ for two minutes. The musts were normalized to ambient temperature after which the yeast culture was added at the rate of 0.2 per cent.

\section{Organoleptic evaluation of wine}

The organoleptic evaluation of wine was carried out by scoring wines numerically on a
20 point score card under six categories of sensory quality characteristics viz., appearance, colour, aroma and bouquet, total acidity, sweetness, body, flavour, astringency and general quality. The wine samples along with grape wine as a reference check was served for sensory evaluation. The average values of the scores given by a panel of 6 judges have been reported. The wine with score range of 9 to 12 out of 20 was regarded as commercially acceptable wine, those with a score range of 13 to 16 as standard wine and with a score range above 17 out of 20 were regarded as superior quality wine as per the rating given by Ough and Baker (1961). The wines with score below 9 were rated as unacceptable.

\section{Development of score card}

All wine samples were evaluated by a semi trained panel which consisted of 6 members. The evaluation was carried out using a twenty point scale (Amerine et al., 1972) which was based mainly on the appearance, colour, aroma, sweetness and overall acceptability.

\section{Statistical analysis}

The data recorded on the physico-chemical and organoleptic parameters were subjected to statistical analysis in CRD using ICAR research complex for Goa, (Web Agri Stat Package 2). Interpretation of the data was carried out in accordance with Panse and Sukhatme (1985). The level of significance used in ' $F$ ' test was $p=0.05$. Critical difference values were calculated wherever ' $F$ ' test was significance.

\section{Results and Discussion}

The wine produced from thermovinification and must of pulp and skin $\left(\mathrm{T}_{8}\right)$ secured the highest score of $16.35,16.77$ and 17.40 out of 20 at fresh, three and six months of ageing, respectively. Significantly lowest total scores 
of $9.01,9.97$ and 11.09 out of 20.00 were found in $\mathrm{T}_{1}$ (Juice) at fresh, three and six months, respectively during ageing in cold condition. The results are in line with Somesh et al., (2009) who reported that, among the three different maceration methods viz, thermovinification, carbonic maceration and fermentation on skin, the maximum mean sensory score was reported in thermovinified wine (16.05 out of 20).

Sensory quality parameters viz., appearance, colour, aroma and bouquet, body, flavours were found to be significant among the treatments. The treatment $\mathrm{T}_{8}$ (Thermovinification - Pulp + Skin) secured the highest score which might have extracted good amount of polyphenols and anthocyanins present on the fruit. Francis et al., (1999) suggested that the transfer of glycosides from skins, and their subsequent hydrolysis, might enhance the flavour of wine. Heating grapes increases the permeability of epidermal cells, allowing anthocyanins to move into the juice (Coffelt and Berg, 1965, Rankine, 1973). Similarly, Somesh et al., (2009) reported that, appearance and taste of wine is very complex and depends on a number of factors such as cultivars, agriculture land, vinification practices, fermentation and maturation. Fresh wine aroma, widely considered to be a key aspect of quality is the result of interaction between components of the fruits themselves and those produced during processing, fermentation and ageing and the consumers sense of smell (Sanchez et al., 2005) (Table $1)$.

Table.1 Influence of cold soaking, thermovinification and must type on sensory scores for appearance, colour and aroma and bouquet of jamun wine during ageing

\begin{tabular}{|c|c|c|c|c|c|c|c|c|c|}
\hline \multirow{3}{*}{ 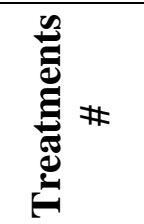 } & \multirow{2}{*}{\multicolumn{3}{|c|}{$\begin{array}{l}\text { Appearance }(0-2) \\
\text { Ageing in months }\end{array}$}} & \multirow{2}{*}{\multicolumn{3}{|c|}{$\begin{array}{c}\text { Colour (0-2) } \\
\text { Ageing in months } \\
\end{array}$}} & \multirow{2}{*}{\multicolumn{3}{|c|}{$\begin{array}{c}\text { Aroma and Bouquet (0-4) } \\
\text { Ageing in months }\end{array}$}} \\
\hline & & & & & & & & & \\
\hline & Initial & 3 & 6 & Initial & 3 & 6 & Initial & 3 & 6 \\
\hline $\mathrm{T}_{1}$ & $0.88^{\mathrm{d}}$ & $0.96^{\mathrm{d}}$ & $1.18^{f}$ & $0.89^{f}$ & $0.98^{\mathrm{d}}$ & $1.11^{\mathrm{c}}$ & $2.10^{\mathrm{e}}$ & $2.19^{f}$ & $2.38^{\mathrm{e}}$ \\
\hline $\mathrm{T}_{2}$ & $0.94^{\mathrm{d}}$ & $0.98^{\mathrm{d}}$ & $1.19^{\mathrm{f}}$ & $0.92^{\mathrm{f}}$ & $1.01^{\mathrm{d}}$ & $1.13^{\mathrm{c}}$ & $2.30^{\mathrm{d}}$ & $2.37^{\mathrm{e}}$ & $2.60^{\mathrm{d}}$ \\
\hline $\mathrm{T}_{3}$ & $1.07^{\mathrm{c}}$ & $1.11^{\mathrm{c}}$ & $1.26^{\mathrm{e}}$ & $0.99^{\mathrm{e}}$ & $1.05^{\mathrm{d}}$ & $1.16^{\mathrm{c}}$ & $2.34^{\mathrm{d}}$ & $2.38^{\mathrm{e}}$ & $2.56^{\mathrm{d}}$ \\
\hline $\mathrm{T}_{4}$ & $1.14^{\mathrm{bc}}$ & $1.20^{\mathrm{b}}$ & $1.30^{\text {cde }}$ & $1.19^{\mathrm{d}}$ & $1.24^{\mathrm{bc}}$ & $1.29^{b}$ & $2.54^{\mathrm{c}}$ & $2.58^{\mathrm{d}}$ & $2.68^{\mathrm{cd}}$ \\
\hline $\mathrm{T}_{5}$ & $1.17^{b}$ & $1.21^{\mathrm{b}}$ & $1.29^{\mathrm{de}}$ & $1.17^{\mathrm{d}}$ & $1.23^{\mathrm{c}}$ & $1.30^{\mathrm{b}}$ & $2.63^{b c}$ & $2.66^{\mathrm{cd}}$ & $2.85^{\mathrm{b}}$ \\
\hline $\mathrm{T}_{6}$ & $1.22^{b}$ & $1.27^{b}$ & $1.36^{\mathrm{c}}$ & $1.21^{\mathrm{d}}$ & $1.24^{\mathrm{bc}}$ & $1.29^{b}$ & $2.73^{\mathrm{b}}$ & $2.83^{b}$ & $2.99^{b}$ \\
\hline $\mathrm{T}_{7}$ & $1.20^{\mathrm{b}}$ & $1.24^{\mathrm{b}}$ & $1.35^{\mathrm{cd}}$ & $1.27^{\mathrm{c}}$ & $1.31^{\mathrm{b}}$ & $1.34^{\mathrm{b}}$ & $2.62^{b c}$ & $2.76^{b c}$ & $2.83^{b c}$ \\
\hline $\mathrm{T}_{8}$ & $1.75^{\mathrm{a}}$ & $1.79^{\mathrm{a}}$ & $1.84^{\mathrm{a}}$ & $1.64^{\mathrm{a}}$ & $1.67^{\mathrm{a}}$ & $1.76^{\mathrm{a}}$ & $3.26^{\mathrm{a}}$ & $3.47^{\mathrm{a}}$ & $3.61^{\mathrm{a}}$ \\
\hline $\mathrm{T}_{9}$ & $1.68^{\mathrm{a}}$ & $1.73^{\mathrm{a}}$ & $1.77^{\mathrm{b}}$ & $1.56^{\mathrm{b}}$ & $1.61^{\mathrm{a}}$ & $1.73^{\mathrm{a}}$ & $3.29^{\mathrm{a}}$ & $3.44^{\mathrm{a}}$ & $3.56^{\mathrm{a}}$ \\
\hline Mean & 1.23 & 1.28 & 1.39 & 1.20 & 1.26 & 1.35 & 2.64 & 2.74 & 2.90 \\
\hline S. Em \pm & 0.03 & 0.03 & 0.01 & 0.02 & 0.02 & 0.02 & 0.04 & 0.05 & 0.06 \\
\hline CD $5 \%$ & 0.10 & 0.08 & 0.05 & 0.05 & 0.06 & 0.06 & 0.15 & 0.16 & 0.17 \\
\hline
\end{tabular}

\# Refer methodology for treatment details

Different alphabets within the column are significantly different $(\mathrm{p}=0.05)$ according to Duncan's Multiple Range Test 
Table.2 Influence of cold soaking, thermovinification and must type on sensory scores for Acidity, sweetness and body of jamun wine during ageing

\begin{tabular}{|c|c|c|c|c|c|c|c|c|c|}
\hline \multirow{3}{*}{ 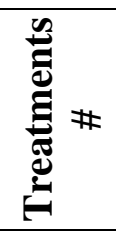 } & \multirow{2}{*}{\multicolumn{3}{|c|}{$\begin{array}{c}\text { Acidity (0-2) } \\
\text { Ageing in months } \\
\end{array}$}} & \multirow{2}{*}{\multicolumn{3}{|c|}{$\begin{array}{c}\text { Sweetness (0-2) } \\
\text { Ageing in months }\end{array}$}} & \multirow{2}{*}{\multicolumn{3}{|c|}{$\begin{array}{c}\text { Body (0-2) } \\
\text { Ageing in months }\end{array}$}} \\
\hline & & & & & & & & & \\
\hline & Initial & 3 & 6 & Initial & 3 & 6 & Initial & 3 & 6 \\
\hline $\mathrm{T}_{1}$ & $0.92^{\mathrm{d}}$ & $0.94^{\mathrm{d}}$ & $1.00^{\mathrm{c}}$ & $0.87^{\mathrm{f}}$ & $0.95^{\mathrm{f}}$ & $1.02^{\mathrm{e}}$ & $0.93^{\mathrm{e}}$ & $1.08^{\mathrm{d}}$ & $1.19^{\mathrm{e}}$ \\
\hline $\mathrm{T}_{2}$ & $0.93^{\mathrm{cd}}$ & $0.99^{\mathrm{d}}$ & $1.03^{\mathrm{c}}$ & $0.95^{\mathrm{ef}}$ & $1.02^{\mathrm{e}}$ & $1.07^{\mathrm{e}}$ & $1.07^{\mathrm{d}}$ & $1.14^{\mathrm{d}}$ & $1.28^{\mathrm{d}}$ \\
\hline $\mathrm{T}_{3}$ & $1.02^{c}$ & $1.14^{\mathrm{c}}$ & $1.22^{\mathrm{b}}$ & $1.01^{\mathrm{e}}$ & $1.12^{\mathrm{d}}$ & $1.17^{\mathrm{d}}$ & $1.25^{\mathrm{c}}$ & $1.30^{c}$ & $1.31^{\mathrm{cd}}$ \\
\hline $\mathrm{T}_{4}$ & $1.15^{b}$ & $1.23^{b c}$ & $1.29^{\mathrm{b}}$ & $1.11^{\mathrm{d}}$ & $1.18^{\mathrm{c}}$ & $1.28^{c}$ & $1.25^{\mathrm{c}}$ & $1.30^{c}$ & $1.36^{\mathrm{c}}$ \\
\hline $\mathrm{T}_{5}$ & $1.19^{b}$ & $1.26^{\mathrm{b}}$ & $1.31^{\mathrm{b}}$ & $1.19^{\mathrm{cd}}$ & $1.26^{\mathrm{b}}$ & $1.36^{\mathrm{bc}}$ & $1.39^{b}$ & $1.44^{\mathrm{b}}$ & $1.47^{\mathrm{b}}$ \\
\hline $\mathrm{T}_{6}$ & $1.18^{b}$ & $1.24^{b c}$ & $1.28^{\mathrm{b}}$ & $1.29^{b}$ & $1.32^{\mathrm{b}}$ & $1.40^{\mathrm{b}}$ & $1.42^{b}$ & $1.47^{b}$ & $1.51^{b}$ \\
\hline $\mathrm{T}_{7}$ & $1.18^{\mathrm{b}}$ & $1.23^{b c}$ & $1.31^{\mathrm{b}}$ & $1.22^{b c}$ & $1.28^{\mathrm{b}}$ & $1.36^{\mathrm{bc}}$ & $1.24^{\mathrm{c}}$ & $1.29^{c}$ & $1.34^{\mathrm{c}}$ \\
\hline $\mathrm{T}_{8}$ & $1.69^{\mathrm{a}}$ & $1.74^{\mathrm{a}}$ & $1.79^{\mathrm{a}}$ & $1.58^{\mathrm{a}}$ & $1.67^{\mathrm{a}}$ & $1.75^{\mathrm{a}}$ & $1.53^{\mathrm{a}}$ & $1.61^{\mathrm{a}}$ & $1.66^{\mathrm{a}}$ \\
\hline $\mathrm{T}_{9}$ & $1.70^{\mathrm{a}}$ & $1.72^{\mathrm{a}}$ & $1.76^{\mathrm{a}}$ & $1.57^{\mathrm{a}}$ & $1.62^{\mathrm{a}}$ & $1.67^{\mathrm{a}}$ & $1.53^{\mathrm{a}}$ & $1.63^{\mathrm{a}}$ & $1.67^{\mathrm{a}}$ \\
\hline Mean & 1.22 & 1.28 & 1.33 & 1.20 & 1.30 & 1.34 & 1.29 & 1.36 & 1.42 \\
\hline $\begin{array}{c}\mathrm{S} . \\
\mathrm{Em} \pm \\
\mathrm{CD}\end{array}$ & 0.03 & 0.03 & 0.02 & 0.03 & 0.03 & 0.03 & 0.03 & 0.02 & 0.02 \\
\hline $5 \%$ & 0.10 & 0.10 & 0.09 & 0.09 & 0.07 & 0.09 & 0.09 & 0.08 & 0.06 \\
\hline
\end{tabular}

\# Refer methodology for treatment details

Different alphabets within the column are significantly different $(\mathrm{p}=0.05)$ according to Duncan's Multiple Range Test

Table.3 Influence of cold soaking, thermovinification and must type on sensory scores for flavour, astringency and general quality colour of jamun wine during ageing

\begin{tabular}{|c|c|c|c|c|c|c|c|c|c|}
\hline \multirow{3}{*}{ 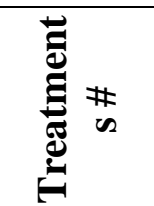 } & \multirow{2}{*}{\multicolumn{3}{|c|}{$\begin{array}{c}\text { Flavour (0-2) } \\
\text { Ageing in months }\end{array}$}} & \multirow{2}{*}{\multicolumn{3}{|c|}{$\begin{array}{l}\text { Astringency (0-2) } \\
\text { Ageing in months } \\
\end{array}$}} & \multirow{2}{*}{\multicolumn{3}{|c|}{$\begin{array}{c}\text { General quality (0-2) } \\
\text { Ageing in months } \\
\end{array}$}} \\
\hline & & & & & & & & & \\
\hline & Initial & 3 & 6 & Initial & 3 & 6 & Initial & 3 & 6 \\
\hline $\mathrm{T}_{1}$ & $0.81^{\mathrm{f}}$ & $0.91^{\mathrm{e}}$ & $1.01^{\mathrm{f}}$ & $0.77^{f}$ & $0.88^{f}$ & $1.05^{\mathrm{e}}$ & $0.84^{\mathrm{h}}$ & $1.08^{\mathrm{e}}$ & $1.15^{\mathrm{i}}$ \\
\hline $\mathrm{T}_{2}$ & $0.93^{\mathrm{e}}$ & $0.96^{\mathrm{e}}$ & $1.05^{\mathrm{f}}$ & $0.81^{\mathrm{f}}$ & $0.90^{\mathrm{f}}$ & $1.08^{\mathrm{e}}$ & $0.96^{\mathrm{g}}$ & $1.11^{\mathrm{e}}$ & $1.19^{\mathrm{h}}$ \\
\hline $\mathrm{T}_{3}$ & $1.01^{\mathrm{d}}$ & $1.14^{\mathrm{d}}$ & $1.19^{\mathrm{e}}$ & $0.95^{\mathrm{e}}$ & $1.03^{\mathrm{e}}$ & $1.17^{\mathrm{d}}$ & $1.05^{\mathrm{f}}$ & $1.19^{\mathrm{d}}$ & $1.27^{\mathrm{g}}$ \\
\hline $\mathrm{T}_{4}$ & $1.20^{c}$ & $1.25^{\mathrm{c}}$ & $1.30^{\mathrm{d}}$ & $1.18^{\mathrm{d}}$ & $1.23^{\mathrm{d}}$ & $1.31^{\mathrm{c}}$ & $1.18^{\mathrm{e}}$ & $1.23^{\mathrm{d}}$ & $1.31^{\mathrm{f}}$ \\
\hline $\mathrm{T}_{5}$ & $1.19^{c}$ & $1.70^{\mathrm{a}}$ & $1.77^{\mathrm{a}}$ & $1.26^{\mathrm{c}}$ & $1.31^{\mathrm{c}}$ & $1.38^{\mathrm{bc}}$ & $1.26^{\mathrm{d}}$ & $1.30^{\mathrm{c}}$ & $1.36^{\mathrm{e}}$ \\
\hline $\mathrm{T}_{6}$ & $1.24^{\mathrm{c}}$ & $1.67^{\mathrm{a}}$ & $1.73^{\mathrm{a}}$ & $1.35^{\mathrm{b}}$ & $1.39^{b}$ & $1.43^{b}$ & $1.36^{\mathrm{c}}$ & $1.40^{\mathrm{b}}$ & $1.45^{\mathrm{c}}$ \\
\hline $\mathrm{T}_{7}$ & $1.25^{\mathrm{c}}$ & $1.28^{\mathrm{c}}$ & $1.34^{\mathrm{d}}$ & $1.27^{\mathrm{c}}$ & $1.34^{\mathrm{bc}}$ & $1.39^{b}$ & $1.28^{\mathrm{d}}$ & $1.36^{\mathrm{b}}$ & $1.41^{\mathrm{d}}$ \\
\hline $\mathrm{T}_{8}$ & $1.63^{\mathrm{a}}$ & $1.48^{\mathrm{b}}$ & $1.50^{\mathrm{b}}$ & $1.58^{\mathrm{a}}$ & $1.62^{\mathrm{a}}$ & $1.69^{\mathrm{a}}$ & $1.69^{\mathrm{a}}$ & $1.72^{\mathrm{a}}$ & $1.79^{\mathrm{a}}$ \\
\hline $\mathrm{T}_{9}$ & $1.54^{\mathrm{b}}$ & $1.40^{\mathrm{b}}$ & $1.44^{\mathrm{c}}$ & $1.60^{\mathrm{a}}$ & $1.62^{\mathrm{a}}$ & $1.67^{\mathrm{a}}$ & $1.63^{b}$ & $1.67^{\mathrm{a}}$ & $1.71^{b}$ \\
\hline Mean & 1.20 & 1.31 & 1.37 & 1.20 & 1.26 & 1.35 & 1.25 & 1.34 & 1.40 \\
\hline S. Em士 & 0.20 & 0.02 & 0.02 & 0.02 & 0.02 & 0.02 & 0.02 & 0.02 & 0.01 \\
\hline CD $5 \%$ & 0.70 & 0.08 & 0.06 & 0.07 & 0.07 & 0.08 & 0.06 & 0.06 & 0.04 \\
\hline
\end{tabular}

\# Refer methodology for treatment details

Different alphabets within the column are significantly different $(\mathrm{p}=0.05)$ according to Duncan's Multiple Range Test 


\section{Treatment details}

\begin{tabular}{|l|l|}
\hline Treatments & Fermentation with \\
\hline $\mathrm{T}_{1}$ Control & Juice \\
\hline $\mathrm{T}_{2}:$ Control & Pulp + Skin \\
\hline $\mathrm{T}_{3}:$ Control & Pulp + Skin + Seed \\
\hline $\mathrm{T}_{4}:$ Cold soak at $8^{\circ} \mathrm{C}$ for 5 days & Juice \\
\hline $\mathrm{T}_{5}:$ Cold soak at $8^{\circ} \mathrm{C}$ for 5 days & Pulp + Skin \\
\hline $\mathrm{T}_{6}:$ Cold soak at $8^{\circ} \mathrm{C}$ for 5 days & Pulp + Skin + Seed \\
\hline $\mathrm{T}_{7}:$ Thermovinification at $82^{\circ} \mathrm{C}$ for 2 minutes & Juice \\
\hline $\mathrm{T}_{8}:$ Thermovinification at $82^{\circ} \mathrm{C}$ for 2 minutes & Pulp + Skin \\
\hline $\mathrm{T}_{9}:$ Thermovinification at $82^{\circ} \mathrm{C}$ for 2 minutes & Pulp + Skin + Seed \\
\hline
\end{tabular}

Note: In all the treatments i.e. Juice, Pulp + Skin, Pulp + Skin + Seed TSS and pH were adjusted to $24^{\circ}$ Brix and 3.2, respectively.

Fig.1 Influence of cold soaking, thermovinification and must type on overall acceptability (Total 20 score) of jamun wine during ageing

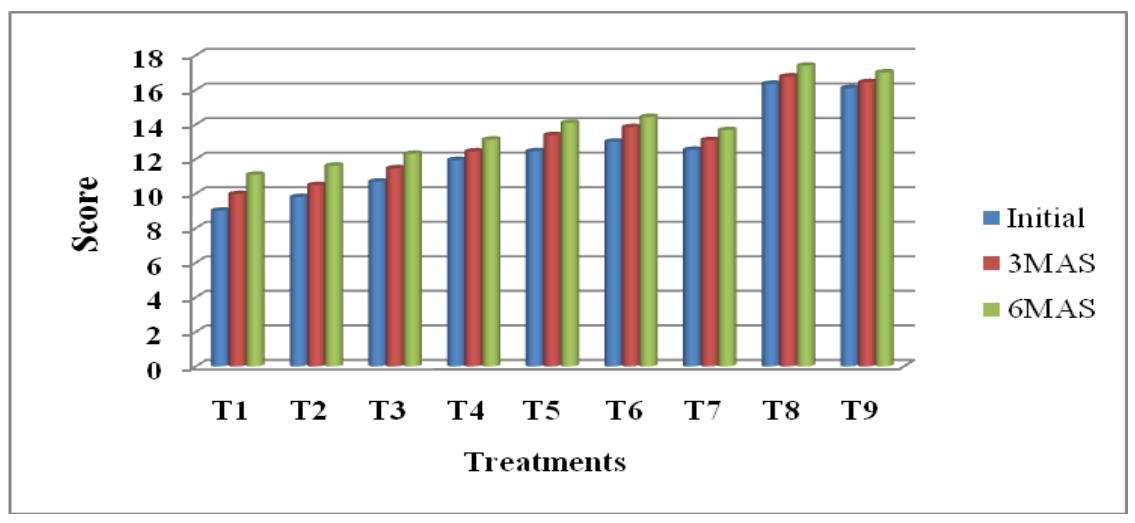

The treatment $\mathrm{T}_{8}$ (Thermovinification - Pulp + Skin) recorded maximum scores for the sensory attributes like acidity, sweetness, astringency and general quality. This might be attributed to the fact that thermovinification of must resulted in the better organoleptic qualities in the wine retained them during the ageing. Similarly, Somesh et al., (2009) concluded that the thermovinified young red wines were found to be less harsh and astringent and comprised of better sensory attributes (Table 2).

The scores in all the treatments showed an increasing trend at six months of ageing than at three months and freshly prepared wines. Due to these changes some of the molecules become so massive that they precipitate resulting in slow smoothening of the taste (Amerine, et al., 1980a). Higher alcohols formed during fermentation decrease with maturation as they are used for the formation of esters. Thus, loss of higher alcohols to form esters is desirable for better sensory properties of wines (Zoeckein et al., 1995). Esters have fruity and floral impact and are important in sensory property of wines. Somesh et al., (2009) in strawberry wine observed an increase in total esters during maturation and they attribute it to the phenomenon of ageing that is desirable for the development of proper flavour (Table 3 and Fig. 1).

In conclusion, the physico-chemical and sensory qualities of the jamun wine are adjusted 
to be best in the treatments involving the thermovinified must containing pulp + skin $\left(\mathrm{T}_{8}\right)$. The general quality of jamun wine can be improved by adopting novel maceration techniques and there is a great scope for utilization of jamun fruits for wine making to reduce the post-harvest loss.

\section{References}

Amerine, M. A., Berg, H. W. and Cruess, W. V., 1972, Technology of wine making, $3^{\text {rd }} \mathrm{Ed}$. Publ: AVI Co. West Port, Connecticut, pp. 126-132.

Amerine, M. A., Borg, H. W., Kunkee, R. E., Ough, C. S., Singletone, V. L. and Webb, A. D., 1980a, The Technology of wine making. $4^{\text {th }}$ Ed. AVI Publ. Co., Westport, Connecticut, U. S. A., pp. 523-547.

Anonymous, 1976, the Wealth of India. Ray Materials, CSIR, New Delhi, 10: 100-104.

Coffelt, R. J., and H. W. Berg, 1965, Color extraction by heating whole grapes. Am. J. Enol. Vitic. 16: 117-128.

Francis, I. L., S. Kassara, A. C. Noble, and P. J. Williams, 1999, The contribution of glycoside precursors to Cabernet Sauvignon and Merlot aroma. In: Chemistry of Wine Flavor. A. L. Waterhouse and S. E. Ebler, (Eds.).ACS Symposium Series 714, Washington, DC. pp 13-30.

Lowe, E. J., Oey, A. and Turner, T. M., 1976.GasquetThermovinification system perspective after two years operation. Am. J. Enol. Vitic.27 (3), 130-133.

McMahon, H. M., Zoecklein, B. W. and Jasinski, Y. W., 1999. The effects of prefermentation maceration temperature and per cent alcohol $(\mathrm{v} / \mathrm{v})$ at press on the concentration of Cabernet Sauvignon grape glycosides and glycoside fractions. Am. J. Enol. Vitic.50 (4), 385-390.
Ough, C. S. and Baker, G. A., 1961, Small panel sensory evaluations of wines by Scoring.Hilgardia, 30 (19): 587-619.

Orchse, J. J., Soule, J. J. Jr., Dijkman, M. J. and Wehbero, C., 1961, Tropical and Subtropical Agriculture. Macmillan, New York, pp. 435-438.

Panse, V. S. and Sukhatme, P. V., 1985, Statistical methods for agricultural workers. Indian Council of Agricultural Research, New Delhi, 152-155.

Rankine, B. C., 1973, Heat extraction from red grapes of increasing importance. Wines and Vines 54 (3): 33-36.

Ribereau-Gayon, P., Dubourdieu, D, Doneche, Band Lonvaud, A., 2000, Handbook of Enology. Vol. 1 and 2 the Microbiology of Wine and Vinifications, John Wiley and Sons Ltd, England, pp. 255-257.

Sacchi, K., Linda, B. and Douglas, A., 2005, A review of the effect of winemaking techniques on phenolic extraction in red wines.Am. J. Enol. Vitic, 56 (3): 197-206.

Sanchez, P. E., Diaz-Marato Hidalgo, M. C., Gonzalez-Vinas, M. A. and Perez-Coello, M. S., 2005, Aroma enhancement in wines from different grape varieties using exogenous glycosidases. Food Chem, 92: 627-635.

Somesh, S., Joshi, V. K. and Ghanshyam, A., 2009, an overview on strawberry wine production technology, Composition, maturation and quality evaluation. Natural Product Radiance, 8 (4): 356-365.

Singh, S., Krishnamurthy, S. and Katyal, S., 1963, Fruit Culture in India. $1^{\text {st }}$ Edn, Indian Council of Agricultural Research, New Delhi, pp. 280-285.

Zoecklein, B. W., Fuglsang, K. C., Gump, B. H. and Nury, F. S., 1995, Wine analysis and production, Chapman Hall, New York.

\section{How to cite this article:}

Hanamant R. Holegar, G.J. Suresha, S.L. Jagadeesh and Vandana, A.K. 2017. Effect of Cold Maceration and Thermovinification on Sensory Evaluation of Jamun (Syzigium cuminii L.) Wine. Int.J.Curr.Microbiol.App.Sci. 6(7): 2733-2738. doi: https://doi.org/10.20546/ijcmas.2017.607.383 